\title{
EKSPLORASI LEGENDA SELANG PANGERAN SEBAGAI BAHAN AJAR BAHASA INDONESIA
}

\author{
Lisa Krisdayani Sitepu ${ }^{1}$, Maria Natalia Situmorang ${ }^{2}$, Wita Dewi ${ }^{3}$, Sri Dinanta Beru \\ Ginting $^{4}$ \\ Universitas Prima Indonesia ${ }^{1}$, Universitas Prima Indonesia ${ }^{2}$, Universitas Prima Indonesia ${ }^{3}$, \\ Universitas Prima Indonesia $^{4}$ \\ Pos-el: lisakrisdayani@gmail.com ${ }^{1}$, liasitumorang3@gmail.com² witadewi04@gmail.com³ \\ sridinantaginting@unprimdn.ac.id ${ }^{4}$
}

\begin{abstract}
ABSTRAK
Legenda adalah cerita prosa rakyat yang dianggap benar-benar terjadi biasanya dihubungkan dengan tokoh sejarah serta dibumbui dengan keajaiban, kesaktian, dan keistimewaan tokohnya. Berdasarkan hal tersebut legenda Selang Pangeran sangat penting untuk diteliti. Penelitian ini berjudul "Eksplorasi Legenda Selang Pangeran sebagai Bahan Ajar Bahasa Indonesia". Penelitian ini diangkat untuk mengeksplorasi bentuk dan maksud dari legenda Selang Pangeran, kemudian mengeksplorasinya menjadi bahan ajar bahasa Indonesia. Penelitian ini bertujuan untuk menambah wawasan siswa tentang legenda tepatnya legenda Selang Pangeran. Penelitian ini menggunakan metode penelitian deskriptif kualitatif bertujuan untuk mendeskripsikan secara sistematis, faktual, dan akurat dengan menggunakan kata-kata atau kalimat. Teknik pengumpulan data menggunakan teknik simak bebas libat cakap. Data dalam penelitian ini adalah data lisan berupa cerita rakyat legenda Selang Pangeran. Sumber data dalam penelitian ini adalah informan dari masyarakat di desa Landak kabupaten Langkat. Teknik analisis data menggunakan analisis interaktif, yaitu reduksi, penyajian data, dan penarikan simpulan. Teknik validitas data menggunakan triangulasi teori dan sumber. Prosedur penelitian meliputi perencanaan, pelaksanaan, dan peyusunan laporan. Luaran dari penelitian ini adalah sebagai bahan ajar bahasa Indonesia, dan artikel yang dipublikasikan.
\end{abstract}

Kata Kunci: Eksplorasi, Legenda, Bahan Ajar.

\begin{abstract}
Legend is a story of people's prose that is considered truly happening usually associated with historical figures and flavored with miracles, supernatural powers, and special features. Based on this, the legend of the Prince Hose is very important to study. This research is entitled "Exploration of Selang pangeran Legend as Indonesian Language Teaching Material". This research was appointed to explore the shape and purpose of the legend of Selang Pangeran, then explore it into Indonesian teaching materials. This study aims to broaden students' knowledge of the legend of the legend of Selang Pangeran. This study uses descriptive qualitative research methods aimed at describing systematically, factually, and accurately by using words or sentences. The technique of collecting data uses proficient free listening techniques. The data in this study are oral data in the form of folklore legend of Selang Pangeran. The data source in this study was informants from the community in the village of Landak, Langkat district. Data analysis techniques use interactive analysis, namely reduction, presentation of data, and drawing conclusions. The data validity technique uses triangulation theory and sources. Research procedures include planning, implementing, and compiling reports. The output of this research is as Indonesian teaching materials, and published articles.
\end{abstract}

Keywords: Exploration, Legend, Teaching Materials. 


\section{PENDAHULUAN}

Sastra lisan pada dasarnya adalah sastra dalam bentuk ujaran yang diceritakan dari mulut ke mulut. Selain itu, sastra juga dikatakan kebudayaan yang diwariskan secara turun temurun oleh masyarakat. Sama halnya seperti yang dikemukakan oleh Danandjaja (2002:19) Sastra lisan merupakan bagian dari kehidupan sastra yang memiliki posisi sangat penting dalam masyarakat. Selain itu, sastra lisan mempunyai banyak sekali fungsi yang menjadikannya sangat menarik serta penting untuk di selidiki oleh ahli-ahli ilmu masyarakat dan psikologi dalam rangka melaksanakan pembangunan bangsa.

Satu diantara sastra lisan adalah legenda. (Danandaja 2002 : 66) Legenda bersifat sekuler "keduniawian" terjadinya pada masa yang begitu lampau, dan bertempat di dunia seperti dunia yang kita kenal sekarang. Legenda sering dipandang tidak hanya cerita belaka namun juga di pandang sebagai "sejarah" kolektif namun hal itu juga sering menjadi perdebatan mengingat cerita tersebut karena kelisannya telah mengalami distorsi. Maka, apabila legenda akan dijadikan bahan sejarah harus dibersihkan dahulu dari unsurunsur folklornya. yang merupakan salah satu warisan budaya yang harus dilestarikan .

Adapun ciri-ciri legenda yang dikemukakan (Rusyana, dkk 2000 : 38) mengemukakan beberapa ciri legenda sebagai berikut : 1) Para pelaku dalam legenda dibayangkan sebagai pelaku yang betul - betul hidup pada masa lalu. Mereka tergolong orang-orang yang terkemuka, misalnya Syekh Muhammad Arsyad yang menyebarkan agama islam. 2) Pelaku lainnya juga orang terkemuka, yaitu orang yang membangun kesejahteraan masyarakat. Misalnya Datuk Sanggul yang suku berburu dan hasil buruannya diserahkan kepada masyarakat. 3) Para pelaku dianggap sebagai pelakusejarah oleh masyarakat setempat, yaitu orang yang hidup pada masa dahulu dan berguna bagi masyarakat. 4)Latar cerita dapat terjadi di sekitar sungai dan dapat pula di luar Indonesia, yaitu Mekah dan Bagdad. 5) Waktu terjadinya peristiwa dibayangkan sebagai masa lalu, tetapi bukan masa purba. 6) Pelaku dan perbuatan pelaku yang dibayangkan benar-benar terjadi menjadikan peristiwa dalam legenda terjadi dalam ruang dan waktu sesungguhnya.

Menurut Jan Harold Bruvand dalam Danandjaja (2002 : 67) mengolongkan legenda menjadi empat kelompok yakni : 1) Legenda Keagamaan (Religious Legend) 2) Legenda Alam Gaib (Supernatural Legend) 3) Legenda Perseorangan (Personal Legend) 4) Legenda Setempat (Local Legends).

Unsur sangat mempengaruhi sebuah karya sastra, unsur ialah yang menyusun sebuah karya sastra dari dalam yang mewujudkan struktur suatu karya sastra (Nurgiyanto, 2007 : 70) yakni : a) Tema, b) Alur, c) Tokoh/Penokohan, d) Setting atau latar, e) Sudut pandang, f) Gaya bahasa, g) Amanat atau pesan

Di Indonesia terdapat berbagai macam legenda yang tersebar dari sabang sampai merauke. Kisahnya diceritakan secara turun temurun dan disampaiakan dari mulut kemulut. Cerita legenda diambil dari mitos, ciri khas masing-masing daerah seperti tempat, binatang, tanaman atau pun berkaitan dengan sejarah yang terjadi di daerah tersebut. Namun, legenda yang semula menjadi identitas suatu daerah kini semakin hari semakin menghilang. Faktor yang mempengaruhi masalah tersebut adalah adanya perkembangan teknologi yang semakin menguasai dunia, sehingga anak zaman sekarang lebih senang bermain gadget dan menonton sinetron dari pada membaca buku-buku tentang sejarah. Dampaknya 
adalah cerita legenda yang mencerminkan suatu daerah dapat tergeser dan terlupakan dan anak-anak dinilai memiliki wawasan yang kurang tentang kebudayaan yang berasal dari daerahnya masing-masing.

Eksplorasi legenda merupakan salah satu upaya menggali lebih dalam legenda yang masi diwariskan secara turun temurun di masyarakat. Legenda masih perlu di eksplorasi untuk mengetahui asal mula cerita dan nilai luhur yang belum banyak diketahui oleh masyarakat sekarang.

Di dalam konteks eksplorasi ini, legenda yang akan dieksplorasi adalah "Selang Pangeran". Legenda tersebut diketahui berasal dari daerah Bahorok Kabupaten Langkat. Sebagai masyarakat yang berbudaya, dan menjaga nilai luhur masyarakat Bahorok mewariskan legenda tersebut dalam bentuk sastra lisan.

Bentuk legenda tersebut bercerita tentang seorang saudagar bernama Datuk Landak yang mencari sumber mata air untuk mengaliri tanaman padinya hingga pada akhirnya ia menemukan sebuah air terjun. Dengan kekuatan yang ia miliki dan bantuan makhluk penunggu kawasan tersebut ia membentuk sebuah aliran yang dinamakannya Selang. Kemudian kawasan air terjun itu dijadikannya tempat pertapaan untuk menuntut ilmu. Tempat itu juga dijadikan para pangeran untuk berguru menuntut ilmu pada Datuk Landak. Dari sanalah awal mula masyarakat menyebut tempat tersebut dengan nama Selang Pangeran.

Adapun hal-hal yang berkaitan dengan eksplorasi legenda "Selang Pangeran" adalah: a) asal legenda "Selang Pangeran" sesungguhnya, b) maksud yang tersimpan dari legenda "Selang Pangeran", mendokumentasikan legenda "Selang Pangeran" dalam bentuk bahan ajar kesusasteraan.

Pada akhirnya penulis mempunyai gagasan untuk menceritakan ulang dan dikenalkan kepada siswa-siswi sekolah menengah pertama. Penulis memilih salah satu cerita legenda berasal dari Sumatera tepatnya dari daerah kabupaten Langkat kecamatan Bahorok di desa Landak. Legenda ini menceritakan tentang sebuah air terjun dan beberapa orang-orang hebat yang memiliki kekuatan gaib. Cerita ini dianggap dapat menjadi bahan ajar dalam mata pelajaran Bahasa Indonesia tentang menulis cerita rakyat. Hal tersebut agar siswa-siswi SMP Bahorok dapat mengetahui kekayaan budaya yang ada disekitarnya dan dapat mempublikasinya.

\section{METODE PENELITIAN}

Dalam penelitian ini penulis menggunakan metode penelitian deskriptif kualitatif. Penggunan metode ini bertujuan untuk membuat deskripsi, gambaran, atau lukisan secara secara sistematis, faktual, dan akurat dengan menggunakan kata-kata atau kalimat. Semuanya diuraikan sesuai dengan kenyataan yang ditemukan di lapangan saat penelitian. Berdasarkan data dan sumber data yang dibutuhkan maka penelitian ini termasuk dalam penelitian deskriptif lapangan karena peneliti terlibat langsung kelapangan untuk mengumpulkan data tentang legenda Selang Pangeran yang dibutuhkan dalam penelitian.

Lokasi yang diambil dalam penelitian ini dilakukan di Desa Landak, Kec. Bahorok, Sumatera Utara. Dengan alasan di desa itulah awal mulanya terdapat legenda "Selang Pangeran". Data pada penelitian ini adalah data lisan berupa legenda "Selang Pangeran". Sumber data yang di dapat dalam penelitian ini adalah informan dari masyarakat yang tinggal di Bahorok. Sumber data tersebut kemudian di catat dari informan yang menuturkannya. Informan yang dimaksud dalam penelitian ini adalah masyarakat setempat. Lama penelitian dilakukan 
selama satu tahun yakni mulai dari November 2018 - Oktober 2019.

Setelah mengumpulkan data dari beberapa informan. Selanjutnya akan dilakukan teknik analis data. Teknik analisis data yang digunakan pada penelitian data yakni teknik analisis interaktif. Langkah-langkah anlisis data terdiri dari tiga alur kegiatan yang terjadi secara bersamaan yaitu: reduksi data, penyajian data, penarikan kesimpulan/verifikasi (Miles \& Huberman, 2007: 16).

Pengumpulan data penelitian ini diperoleh dari hasil wawancara, observasi dan dokumentasi. Proses pengambilan data dilakukan dengan mewawancarai informan dengan cara membuat daftar pertanyaan dan peralatan yang digunakan dalam mendokumentasikan hasil penelitian agar lebih akurat.

Selanjutnya dilakukan reduksi data. Reduksi data merupakan proses pemilihan, pemusatan perhatian pada penyederhanaa, pengabstrakan, transformasi data kasar yang muncul dari catatan-catatan lapangan (Milesdan Huberman, 2007 :16). Dari data yang diperoleh dilakukan penyaringan data yang mendukung dan tidak mendukung. Lalu data yang mendukung berkaitan dengan "Eksplorasi Legenda Selang Pangeran Sebagai Bahan Ajar Bahasa Indonesia".

Setelah data direduksi selanjutnya dilakukan penyajian data. Penyajian data merupakan sebagai sekumpulan informasi tersusun yang memberikan kemungkinan adanya penarikan kesimpulan dan pengambilan tindakan (Miles dan Huberman, 2007 : 17). Dari data tersebut dianalisis sehingga diperoleh deskripsi mengenai bentuk legenda "Selang Pangeran".

Selanjutnya tahap validitas data Menurut Sugiyono (2006 : 267), Validitas merupakan "derajat ketetapan antara data yang terjadi pada objek penelitian dengan daya yang dapat dilaporkan oleh peneliti". Teknik validitas data dapat dilakukan dengan teknik trianggulasi. Trianggulasi merupakan teknik pemeriksaan keabsahan data dengan memanfaatkan sesuatu yang lain diluar data itu untuk keperluan pengecekan data atau sebagai pembanding terhadap data itu (Sugiyono, 2006 : 207).

Kemudian tahap pelaksanaan, pada tahap ini, meliputi pengumpulan data, pengelompokan, analisis data, dan penarikan kesimpulan. Tahap pengumpulan data, peneliti melalui dua tahap, yaitu mengumpulkan data dari informan untuk memperoleh bentuk legenda "Selang Pangeran" secara lengkap sebagai bahan ajar Bahasa Indonesia.

Selanjutnya tahap penyusunan laporan menjadi tahap terakhir dalam prosedur penelitian. Tahap ini dilakukan peneliti setelah semua data yang dibutuhkan telah terkumpul, telah direduksi, telah dianalisis, dan telah disimpulkan. Tahap ini adalah tahap dimana peneliti memindahkan hasil penelitian yang di dapat dalam bentuk laporang yang bersifat ilmiah.

\section{HASIL DAN PEMBAHASAN \\ a. Deskripsi Bentuk Legenda "Selang Pangeran"}

Hampir disetiap daerah di Indonesia memiliki legendanya sendiri, tak terkecuali di daerah Bahorok Kabupaten Langkat. Terdapat legenda "Selang Pangeran". Legenda ini belum banyak dikenal oleh masyarakat setempat karena keingintahuan mereka terhadap legenda "Selang Pangeran" sangat kurang. Sehingga mengakibatkan bentuk cerita legenda "Selang Pangeran" itu sendiri hilang termakan masa.

Nama "Selang Pangeran" sendiri dimaksudkan untuk menyebut sebuah air terjun yang terdapat di Bahorok tepatnya di Desa Landak. Berawal dari seorang saudagar yang bernama Datuk Landak datang dari negeri seberang. Dimana Datuk Landak ini mencari tempat yang 
tepat untuk berdagang, hingga sampailah dia di Bahorok. Selanjutnya dia memulai usahanya dari nol lagi dan berencana ingin tinggal di daerah Bahorok yaitu di desa Landak. Di desa itu ia mulai berdagang dan bercocok tanam dengan harapan akan keberuntungan menghampirinya.

Untuk pertama kalinya Datuk Landak mencoba menanam padi satu karung, sewaktu panen juga mendapat keuntungan satu karung. Tapi ada yang membuat Datuk Landak heran dengan padi hasil panennya, walaupun sudah dia masak berulang kali tidak pernah berkurang dan tetap sama seperti pertama kali dipanen. Selanjutnya Datuk Landak tersebut mengatakan kepada warga yang tinggal di desa Landak bahwasannya tanah tempat mereka tinggal itu adalah tanah bertuah. Perkataanya itu membuat warga desa heran, sebab selama ini desa itu terus dilanda kekeringan dan menyebabkan gagal panen. Hingga pada suatu hari desa Landak semakin parah kekeringannya, padi Datuk Landak pun terikut terkena dampak kekeringan. Datuk Landak mencari cara bagaimana agar bisa mengairi lahan persawahan yang ada di daerah desa Landak itu. Dengan tekad yang kuat Datuk Landak pergi kepedalaman hutan mencari sumber mata air untuk di alirkan ke sawah di desa Landak. Datuk Landak memang seorang yang tidak kenal menyerah walaupun diperjalanan melewati batu-batu yang terjal dan licin. Karena kegigihan yang dimiliki Datuk Landak menemukan sebuah air terjun di tengah hutan.

Diceritakan bahwa Datuk Landak mencari cara bagaimana caranya agar bisa mengairi persawahan yang kekeringan di desanya dengan air terjun yang di temukan di hutan. Datuk Landak diceritakan sebagai seorang yang memiliki kekuatan supranatural. Sehingga dia dapat membendung air kedalam sebuah gua yang ada di sekitaran air terjun. Bukan hanya itu Datuk Landak juga meminta pertolongan pada makhluk-makhluk gaib yang tinggal di daerah tersebut. Tanpa dapat di percaya akal sehat terbentuklah sebuah aliran air yang disebut "Selang" yang bisa sampai mengairi tanaman di Desa. Air terjun yang menjadi sumber mata air bagi warga di desa Landak dijadikan Datuk Landak sebagai tempat menuntut ilmu. Karena dikawasan air terjun dianggap masih sangat sakral dan dijaga oleh Datuk Landak.

Diceritakan juga bahwa kehebatan dan kejayaan Datuk Landak tersiar kesemua penjuru daerah. Hingga sampai ketelinga seorang Pangeran Bahorok, yang membuatnya ingin segera datang ketempat Datuk Landak. Pangeran datang dengan harapan mendapat izin bisa menuntut ilmu di tempat yang menjadi perbincangan orang banyak. Sang pangeran juga meminta untuk diberikan ilmu-ilmu yang dimiliki Datuk Landak.

Datuk Landak mengatakan bahwa dia memberi persyaratan kepada siapa saja yang ingin berguru dengannya. Yaitu dengan syarat bertapa selama 40 hari 40 malam dibawah air terjun didekat selang yang dia buat. Hingga ilmu yang di peroleh selama bertapa akan di sempurnakan dengan menguji apakah lulus atau tidak. Datuk Landak menguji siapa saja yang mentut ilmu dengan menaruh mangkuk dengan ukiran khas di kanan dan kiri pundak, juga di atas kepala. Jika mangkung yang Datuk Landak pecahkan melukai bagian tubuh mereka akan dinyatakan gagal. Namun pangeran dinyatakan lulus karena tak ada satupun mangkuk yang dipecahkan melukai tubuhnya. Selanjutnya diceritakan bahwa pangeran yang lulus dan memiliki kekuatan, sering membantu orang-orang yang kesusahan. Sehingga pangeran terus disanjung akan kekuatannya. Semua orang penasaran dari mana pangeran bisa memiliki kekuatan itu. Pada akhirnya orang-orang 
mengetahui rahasia pangeran yang berguru pada Datuk Landak di kawasan "Selang" yang dibuat Datuk Landak. Dari sanalah nama "Selang Pangeran" terbentuk, karena banyak pangeranpangeran yang berlomba ingin kesaktian dan menuntut ilmu di kawasan air terjun yang ditemukan oleh Datuk Landak.

\section{b. Bentuk Legenda "Selang Pangeran"}

Datuk Landak seorang saudagar yang berasal dari negeri seberang. Bertahun-tahun menjadi pedagang. Suatu saat ia berkelana mencari tempat yang berpeluang besar untuk ia berdagang. Akhirnya ia memutuskan untuk pergi kedaerah Sumatra Utara tepatnya di Kabupaten Bahorok. Disana ia memulai usahanya dari nol. Bukan hanya berdagang, ia juga ingin mencari tempat tinggal disana. Berjalan kesana kemari menelusuri perkampungan hingga sampailah ia ke sebuah desa di daerah kecamatan Bahorok. Di tempat itu, ia mulai bercocok tanam. Pernah ia menanam padi satu karung dan panen dengan hasil yang sama. Namun ada yang membuatnya tercengang. Hasil panennya itu tidak pernah habis walau sudah berkali-kali digunakannya untuk memasak. Sejak saat itu Datuk Landak mengatakan bahwasannya tanah di desa itu tanah bertuah. Para warga pun heran dengan perkataannya itu, bagaimana mungkin tanah yang kita tempati sekarang ini adalah tanah bertuah? Sedangkan kita menamam padi saja tidak pernah berhasil, melainkan kekeringan semua.

Pada masa itu musim kemarau pun makin menjadi di desa tempat tinggal Datuk Landak. Hingga membuat tanaman padinya juga ikut kekeringan. Semua lahan di daerah itu semakin tandus dan tak dapat di bajak. Semua warga pun bersedih melihat tanaman yang mereka tanam mengering seperti kerupuk. Datuk Landak mulai kebingungan. Ia pun mencari akal untuk mendapatkan sumber air agar padinya dan seluruh warga dapat dialiri.

Datuk Landak menelusuri pedalaman hutan untuk mencari mata air. Sudah berhari-hari ia mencari tak kunjung mendapatkan hasil. Ia masuk ke hutan yang tidak pernah terjamah oleh manusia, melewati batu-batu terjal dan pepohonan yang sangat besar. Ia juga sering berjumpa dengan hewan-hewan buas. Namun ia tetap teguh dan berjuang, untuk memakmurkan desanya yang sekarang mengalami kekeringan. Hingga pada akhirnya ia menemukan sebuah air terjun. Di bawah air terjun tersebut mengalir sebuah sungai yang sangat indah. Datuk Landak mulai berpikir bagaimana ia bisa mengaliri desanya dengan air terjun itu ke tanaman padinya dan warga. Dengan kekuatan yang dimilikinya, ia membendung air kedalam sebuah gua yang terdapat di pinggiran sungai. Dia juga meminta izin kepada makhluk-makhluk penunggu daerah itu untuk membangun sebuah aliran. Dibuat dengan bahan-bahan yang tersedia di dekat sungai itu. Hingga membentuk sebuah aliran yang di sebut dengan selang karena aliran itu diselingi batu-batu besar yang membuat air bisa sampai mengaliri tanamannya.

Datuk Landak memilih air terjun itu untuk tempat bertapa dan menuntut ilmu. Karena daerahnya yang dikatakan masih perawan dan belum terjamah oleh tangan-tangan yang tidak bertanggungjawab. Hingga tempat itu menjadi tempat paling sakral yang dihormati dan dijaganya.

Kehebatan dan kejayaan Datuk Landak terdengar hingga kepenjuru daerah. Tak terkecuali pada salah seorang pangeran bahorok yang ingin segera mendatangi Datuk Landak dan menuntut ilmu di daerah air terjun yang menjadi buah bibir orang-orang di setiap daerah. Sesampainya di tempat tinggal Datuk Landak, pangeran pun meminta izin untuk di ajarkan ilmu-ilmu yang dimilikinya. Datuk landak pun memberi 
beberapa persyaratan kepada pangeran salah satunya adalah bertapa di bawah air terjun didekat selang yang ia buat. Setelah bertapa selama 40 hari 40 malam pangeran pun di jemput oleh Datuk Landak untuk menyempurnakan ilmu pangeran yang di dapatnya selama bertapa. Sama dengan kebanyakan orang yang telah datang ke air terjun itu untuk menuntut ilmu. Datuk landak akan menaruh beberapa mangkuk putih dengan ukiran yang sangat khas dan menaruhnya ke bagian kanan, kiri pundak dan kepala. Lalu memecahkanya dengan tangan kosong. Jika mangkuk pecah dan melukai bagian tubuh maka dinyatakan gagal. Karena mungkin pada sebagian orang yang menuntut ilmu itu berniat jahat dan ingin menyalahgunakannya. Sedangkan pangeran yang dinyatakan lulus, tidak satupun pecahan mangkuk itu melukai bagian tubuh. Sehingga ia memiliki kekuatan dan digunkannya untuk membantu orang-orang.

$$
\text { Masyarakat menyanjung }
$$

pangeran akan kekuatan yang diperolehnya. Mereka yang dibantu oleh pangeran mengetahui rahasia kekuatan yang dimiliki pangeran yaitu berguru dan menuntut ilmu di daerah Datuk Landak. Dari sanalah orang-orang menyebut tempat itu dengan sebutan Selang Pangeran. Karna begitu banyak pangeran-pangeran yang bertapa ingin mendapatkan ilmu yang sakti di air terjun tersebut. Setelah beberapa ribu tahun akhirnya Datuk Landak pun meninggal dan kampung yang dahulu ditinggalinya kini dinamakan desa Landak.

\section{c. Maksud Legenda "Selang Pangeran"}

Terkait legenda "Selang Pangeran" dapat dipahami pesan atau maksud yang disampaikan didalamnya, bahwasanya cerita ini memiliki makna yang sangat berharga bagi kehidupan manusia. Legenda ini mengajarkan kita supaya tidak mudah menyerah dalam menggapai sebuah tujuan walaupun hal itu sulit untuk dicapai. Keberanian serta tekat yang kuat juga diperlukan untuk menghadapi rintangan yang ada. Misalnya pada kata "Selang Pangeran", selang yang dimaksud didalamnya adalah selang yang terbuat dengan susah payah dan kerja keras. Dalam pembuatannya harus memerlukan kesabaran yang tinggi supaya mendapatkan hasil yang memuaskan. Seperti tokoh Datuk Landak yang memperlihatkan kerja kerasnya dan tidak pernah mengeluh walaupun terus mengalami kegagalan. Sedangkan kata pangeran, diambil dari peristiwa bahwa dulu di daerah air terjun tempat Datuk Landak bertapa sering datang pengeranpangeran untuk menuntut ilmu.

Legenda ini juga mengajarkan kita untuk mengikuti aturan-aturan yang ada untuk mendapatkan pelajaran yang sangat berharga. Seperti yang terdapat dalam cerita dimana semua pangeran yang ingin bertapa di daerah air terjuan itu harus mengikuti seua peraturan yang dibuat oleh datuk landak.

\section{d. Relevansi Legenda "Selang Pangeran" Kedalam Pembelajaran Bahasa Indonesia Di Tingkat SMP}

Berdasarkan permasalahan yang terdapat di latar belakang masalah sebelumnya,tentang relevansi legenda "Air terjun selang pangeran", peneliti melibatkan beberapa guru dan beberapa kelas SMP kelas VII di SMP Negeri 1 Bahorok. Berdasarkan hal tersebut, dapat diketahui bahwa relevansi yang dimaksud adalah relevansi dengan pembelajaran bahasa indonesia tentang legenda atau cerita rakyat di sekolah menengah pertama.

Sekolah menengah pertama dianggap memiliki relevansi dengan hal yang dikaji dalam penelitian ini. Karna aspek yang diteliti merupakan materi pelajaran dalam mata pelajaran bahasa 
indonesia tepatnya pada topik tentang cerita rakyat. Namun dalam pembelajaran ini terfokus pada siswa kelas VII. Karna siswa kelas VIII dan IX tidak memuat pembelajaran tentang cerita rakyat. Legenda "Air terjun selang pangeran" ini juga tepat untuk dijadikan sebagai bahan ajar, karna akan lebih kreatif jika pembelajaran tentang cerita rakyat menggunakan cerita rakyat setempat. dan akan menambah wawasan meraka tentang daerahnya dan juga dapat merangsang keingintahuan siswa untuk mengetahui lebih dalam Legenda Selang Pangeran. Agar siswa tidak pasif tentang legenda atau pun cerita-cerita rakyat yang ada di sekitar mereka. Menggunakan cerita rakyat Legenda Selang Pangeran juga dapat meningkatkan kecintaan siswa terhadap cerita rakyat yang ada di sekitar mereka. bukan tidak mungkin dengan memperkenalkan cerita rakyat legenda selang pangeran tersebut siswa berinisiatif ingin mempublik legendalegenda lain yang mereka ketahui di sekitar mereka.

Berdasarkan penelitian, diperoleh relevansi tentang legenda "Air terjun selang pangeran" dimana pembelajaran tentang legenda merupakan materi pembelajaran di sekolah menengah pertama pada kelas VII. Hal tersebut dinyatakan di silabus Kementerian pendidikan dan kebudayaan (2017) serta berdasarkan hasil wawancara mendalam dengan guru di SMP Negeri 1 Bahorok.

Dengan memperkenalkan legenda selang pangeran ini, siswa mampu menambah wawasan mengenai legenda selang pangeran yang ada di Bahorok. Dan dapat memacu dirinya dalam mengeksplor legenda yang terdapat di sekitarnya.

Penelitian ini sejalan dengan penelitian dari Sri Dinanta Beru Ginting dan Bambang Nur Alamsyah pada tahun 2018 yang berjudul "Eksplorasi Cerita Rakyat "Mehangke" Suku Karo Sebagai Bahan Ajar Kesusastraan di Prodi

\section{Pendidikan Bahasa Dan Sastra} Indonesia Universitas Prima Indonesia.

\section{SIMPULAN}

Berdasarkan hasil penelitian yang disajikan pada bab sebelumnya dapat disimpulkan bahwa Legenda Selang Pangeran adalah legenda yang terdapat di Bahorok Kabupaten Langkat. Legenda ini terbentuk dari seorang saudagar yang bernama Datuk Landak. Ia adalah pelopor adanya legenda ini, karna ia yang membuat selang dari air terjun tersebut dan pangeran-pangeran datang ke air terjun untuk bertapa menuntut ilmu melalui Datuk Landak.

Legenda yang disampaikan leluhur dari mulut ke mulut bercerita tentang legenda Datuk Landak yang membawa banyak kebaikan untuk desa itu dengan diciptakannya selang yang membawa kemakmuran. Kata "Selang" diambil dari galian tanah yang berbentuk sungai kecil yang disebut mereka sebagai selang untuk mengaliri air ke persawahan Mereka yang dilanda kekeringan. Sedangkan kata "Pangeran" diambil dari kejadian banyaknya pangeran-pangeran yang datang ke air terjun tersebut untuk bertapa dan menuntut ilmu melalui Datuk Landak.

\section{DAFTAR PUSTAKA}

A, Teeuw. 1984. Sastra dan Ilmu Sastra: Pengantar Teori Sastra. Jakarta: Dunia Pustaka Jaya.

Danandjaja, James. 2007. Folklor Indonesia, Ilmu Gosip, Dongeng, dan Lain-lain. Jakarta: Grafiti.

Endraswara, Suwardi. 2011. Metodologi Penelitian Sastra. Yogyakarta : CAPS

Moleong, Lexy J. 2008. Metodologi Penelitian Kualitatif. Bandung: PT Remaja Rosdakarya.

Mahsun. 2007. Metodologi Penelitian Bahasa: Tahap Strategi, Metode dan Tekniknya. 


\section{Jakarta: PT Raja Grafindo}

Persada.

Miles, Matthew B dan A. Michael

Huberman. 2007. Analisis Data

Kualitatif: Buku Sumber

tentang Metode-metode Baru. Jakarta: UI Press.

Nurgiyantoro, Burhan. 2007. Teori

Pengkajian Fiksi. Yogyakarta:

Gadjah Mada University Press.

Rusyana, dkk. 2000. Prosa Tradisional :

Pengertian, Klasifikasi dan

Teks. Jakarta: Pusat Bahasa.

Sukatman. 2011. Butir-butir Tradisi

Lisan Indonesia. Yogyakarta:

LaksBang PRESSindo.

Sugiyono. 2006. Metode Penelitian

Kuantitatif, Kualitatif dan R \&

D. Bandung : Alfabeta.

Yapi Taum, Yoseph. 2011. Studi Sastra

Lisan. Yogyakarta: Lamalera. 